\title{
Ethics and Governance in The Time of Ramayana
}

\author{
Ruchie Shah ${ }^{1^{*}}$, Mridu Shah \\ ${ }^{1}$ Shri Ram Murti Smarak College of Engineering Technology and Research, Ram Murti Puram, Nainital Rd, Highway, Bhoji Pura, Uttar Pradesh \\ 243202, Bareilly, India \\ ${ }^{2}$ SRM Institute of Science of Technology, Jawaharlal Nehru Rd, Vadapalani, Chennai, Tamil Nadu 600026, India \\ 1"ruchieagar007@gmail.com, ${ }^{*}$ mridusah20@gmail.com
}

ARTICLE INFO

Article history

Received 15 January 2021

Revised 17 March 2021

Accepted 29 April 2021

Keywords

Good governance;

Organisational development;

Ramayana.

\begin{abstract}
This paper employs the epic story of Ramayana for having better understanding of good governance, leadership and strategies for development of organization. Good governance is basic requirement for maintaining peace and harmony in any society. However, good governance has become a rarity in today's world. A large majority of political, business and other leaders are increasingly engaged in self serving pursuits of personal glorification and enrichment. By realizing significance of Ramayan for good governance and leadership, young generation can learn from history and this will encourage various management teachers to develop indigenous case studies based on similar incidences to bring new ideas into management discipline. The practicing managers can find new ideas and strategies for their development and their organisational development.
\end{abstract}

This is an open access article under the CC-BY-SA license

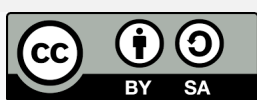

\section{Introduction}

Good governance is basic requirement for maintaining peace and harmony in society. However, in today's world it is rarity. There are plenty of ideas which can enrich our understanding of co-operate governance and leadership.

People expect an elected government to create condition for peace, progress and prosperity. Good governance is basic requirement for maintaining peace and harmony in any society. However, we notice that good governance has become a rarity in today's world. A large majority of political, business and other leaders are increasingly engaged in self -serving pursuits of personal glorification and enrichment. The masses have practically no role in governance. economic progress and prosperity is confined to a handful of top industrialists, who are politically well connected, at the same time the fate of large masses has painfully remained unchanged. Social justice remains a mere slogan at election rallies and in five -star conferences attended by the elite.

In this paper, some characters and situation are taken from Epic Ramayana for having better understanding of good governance, leadership and strategies for development of organization. Also, the present analysis will not only motivate young generation but also encourage faculty to bring new ideas into classroom with the help of case study and live example. 
The paper briefly highlights four points for deriving some ideas from Ramayana [1]. There are plenty of such ideas which can enrich our understanding of corporate governance and leadership. It is wonderful to note that organizations, regulators and academicians have started realizing significance of Ramayan for good governance and leadership. It can motivate the young generation to learn from our history. Also, this will encourage various management teachers to develop indigenous case studies based on similar incidences to bring new ideas into management classroom. The practicing managers can find new ideas and strategies for their development and their organisational development.

India is the land of famous mythologies and folklores and it has rich classical heritage. The land of many great thinkers and writers, our collection of literature in Sanskrit is priceless. Many people think of Sanskrit in terms of chants, hymns and verses. Not many know the vast collection of poetry, drama, stories and even epics in Sanskrit literature. Sanskrit language literature is a very broad category that requires elaborate understanding of this varied language. The Indian epics are full of moral teachings and sacred discourses that are relevant in today's life also.

The two famous works that are synonymous to epic literature of India are Ramayana and Mahabharata. These two classical epics of India are written in ancient Sanskrit and present the most common ideals of human civilization that seem to have gone down the drain in the modern times. The value of truth, the importance of self-sacrifice, etc. that make an able individual are explained in much detail over here.

Many people say that Ramayana is a story of compassion and selflessness, but a stern look will remove these misconceptions. Ramayana was strictly an objectivistic tale based on reasons and uncompromising morals like a democratic society, capitalistic freetrade civilization and virtue of selfishness.

Today the state of affairs of the country in India is very bad indeed. Centuries of foreign rule and occupation have left a legacy of poverty and despair. Large groups in the society are practically neglected, there is a spread of corruption and lawlessness that most of the population has lost hope that the divine exists, let alone that it will ever intervene to establish order and justice. However, the most enduring Indian spirit still exists and hope is not entirely lost.

In this paper, we elaborate the Governance Rules quoted in Valmiki Ramayana [2][3], which are very much applicable today's modern life. Sri Ram symbolizes virtue as he never compromised with anything unethical while upholding the principles of Justice. This is the first principle of Governance. Is it not applicable now?

\section{Method}

This paper draws upon The Ramayana[4] to construct the principle of governance. The Ramayana has a lot to offer to governance and leadership, however, there is a lack of awareness of the message and lessons from Ramayana in leadership in this $21^{\text {st }}$ century. The condition of Lord Vishnu descending on earth was not to be aware about his divine origin from the beginning. Sri Rama behaved like an ordinary mortal. Nothing suggested that he was more than an ordinary prince although he displayed beautiful human qualities, 
being highly intelligent, educated, and respectful to his parents and very much abiding the right conduct (Dharma) in relation to everyone.

Duty has the regular definition of a moral or legal obligation, a responsibility, or a task or action that someone is required to perform. However, in the context of the story of Ramayana, duty, or dharma, has a more specific interpretation. Dharma is a set of laws or principles carried out with the purpose of creating social and religious order in the society. In this story of Ramayana, many times this duty conflicts with other values or personal desires, forcing characters to compare the choices of following the dharma or fulfilling another human value. These values in the story of Ramayana [5][6] are abstracted to construct principle of governance. We quoted some dialogues in the Story of Valmiki Ramayana and relate them to management and organizational development. This paper employed historical method approach [7].

\section{Results and Discussions}

\subsection{Succession Related Matters}

Two exemplary evidences from Ramayana can enlighten us in this subject. First, Bharat even when legally and technically eligible to sit on the throne of Ayodhya, not only declined to accept it but also termed it as unethical and against the spirit. However, at the same time he ensured that his duties and responsibilities of successfully running the Kingdom were fulfilled. He discharges the duties with best of his efforts.

Second, even before winning over Lanka Shri Ram declared that Vibhishana would be the natural successor of Ravana. He did not even want to stay in Lanka for a second after freeing Mata Sita from Ravana. He said to Lakshman - "this golden Lanka does not interest me, mother and motherland are superior than heaven". When Vibhishana's Raj tilak was done, he said, "it comes naturally to me that if I win any kingdom, I don't plunder it's wealth, but try to establish good leadership there".

\subsection{Diversity and Inclusiveness}

Who could be a better example setter than Bhagwan Shri Ram? He managed and led a team with an aggressive Laxman, mighty Sugreev, mercurial monkeys, calm and composed Jamwant, Vibhishan, and Bhakt Hanuman. The most important characteristic was that he listened to all of their diverse views' opinions, strategies and took integrative decision, which was all inclusive and but had unique inputs from his own acumen.

\subsection{Whistle blowing of Vibhishana}

These days whistle blowing is considered very important for transparency and ethical behaviour in a corporate. If we look into Ramayan, we had one of the greatest whistleblowers of all times - Vibhishan. He questioned unethical practices of Ravan, raised voice against it many times. But the most important point is that all was done with a sense of maturity, respect and in a calm and composed manner. He maintained the sanctity and neither wanted to capture Lanka nor oust Ravan. Also, his aim was not to defame Ravan. He wanted that Ravan should be ethical leader and lead the Lanka for long time and for this, Ravan's behaviour and actions were needed to be righteous.

\subsection{Loksangraha}

Socially responsible leadership of Raja Janak has been Hallmark of Bharatiya approach to development. When a leader follows karmayog path in nishkaam karm mode, 
it results in self development as well as the development of the organisation or society. The trusteeship model is a similar approach which ensures that the organisation contributes to the development of the society.

Village administration was also a significant part of the Ancient Indian Political System. A system of giving taxes also prevailed in the ancient society. Taxes such as Pali, Sulk and Bhaga were collected from the people. The revenue was spent for the benefit of the subjects. The Panchayat system used to serve since ancient times and at present it has become an integral part of Indian Administration.

Homestead and arable lands in the village appear to have been owned by individuals or families, while grass lands (khilya) were probably held in common.Agriculture was the principal occupation of the village folk. Cultivated fields were known as Urvara or Kshetra. They were often watered by irrigation canals. The rearing of cattle and other domestic animals was scarcely less important than agriculture. Though mainly an agricultural and pastoral people, the Vedic people were not indifferent to trade and industry. Trade probably consisted mainly of barter. The chief articles of trade, judging by the evidence of the later Samhitas, were clothes, coverlets and skins.

The principal means of transport by land were chariots (ratha) and wagons (anas), the former usually drawn by horses and the latter by oxen. According to one view, navigation was limited to the crossing of rivers in boats, but we have undoubted references to navigators sailing in ships with a hundred oars.

When the two great epics, the Ramayana and Mahabharata, and Upanishads were written, the society and polity described in these epics are not mythological; they have deep historical roots. The Ramayana and Mahabharata deal with social, political, and religious aspects of life and contain within them the broad principles of Hindu religion. The Bhagavad Gita, which is a part of the Mahabharata, deals solely with the basic concepts of Hinduism. The Upanishads are socio-philosophical treatises, dealing with the functioning and governance of society.[8]

\subsection{The Arts of Administration as Depicted in Valmiki Ramayana}

The Ramayana, the saga of Rama's life written by Valmiki, is widely acclaimed as among the greatest of all Indian epics. The narrative is regarded as a veritable treatise on social sciences, offering lessons that transcend both time and space. In fact, this famous Grantha carries useful tips on ethics and values, statecraft and politics, and even general and human resources management.

The professed objective of all governments, down the corridors of history of man, has been to provide and ensure the welfare and happiness of the people through an efficient and good administration. However, despite the advance of civilization and progress in science and technology and efforts through international forums like the United Nations to achieve peace and happiness, the world is riddled with strife, misery and tension.

Any person in charge of administration has to follow certain well tested codes to bless the generation with peace, prosperity and efficiency. In this context, the ancient and many faceted Ramayana is very relevant today as the epic has very many lessons to offer in the art of administration. A deep study of the epic would not only reflect the high level of civilisation that existed during the Ramayana era but would also furnish meaningful guidelines on Public Administration through the medium of several characters. 
At the outset, the epic opens with the administrative setup prevalent in Ayodhya (the capital city). Further, there are the several situations where detailed and wholesome advice is rendered on the art of efficient administration. Some of them are:

1. King Dasharath's advice to Sri Rama on the eve of coronation.

2. Guru Vasistha's advice to Bharata, after cremation of King Dasaratha

3. Sri Rama's questions and advice to Bharata at their historic meeting at Chitrakut.

4. Demoness Surpankha's advice to King Ravana

5. Demon Maareecha's advice to King Ravana

6. King Vali's advice to his son Angada

7. Hanuman's advice to King Sugriva

8. Sri Ram's advice to King Sugriva

9. Vibhishana's Raj Neeti to King Ravana

10. Kumbhakrna's advice to King Ravana

11. Indrajit's Last words to King Ravana

12. King Ravana's Deathbed advice to Sri Ram

Ramayana is not a mere story. It is the history we live every moment of our lives. In the opening verse itself, Ramayana explains how a ruler should be. The importance of this is, he should have good qualities, and then only he can lead the government. The Sage Valmiki once put the following question to Sage Narada, the chief of the hermits and the foremost in the art of expression:

kah nu asmin saampratam loke gunavaan kah ca viiryavaan dharmaj nah ca $k r^{\wedge}$ itaj nah ca satya vaakyo dhr^idha vratah || 1-1-2

caaritrena ca ko yuktah sa.rva bhuteshu ko hitah | vidvaan kah kah samarthah ca kah ca eka priya darshanah || 1-1-3

"Is there any one in this world at present who is full of virtues and at the same time possessed of great prowess, who knows what is right, is well versed in Dharma (religion), who is conscious of service done (grateful), truthful, and of firm resolve?

Who is possessed of right conduct and who is friendly to all living beings? Who is a man of knowledge, who is powerful and who has a singularly lovable appearance. Who has subdued his self, who has conquered anger, who is possessed of splendor and who is above faultfinding and whom the very gods dread when his wrath has been provoked in battle?

I wish to hear this; O eminent Seer!"

Being pleased on hearing these words of Valmiki, the Sage Narada greatly delighted and said:

"Listen! Be please to hear from me of the man endowed with the many and rare virtues and qualities mentioned by you." 


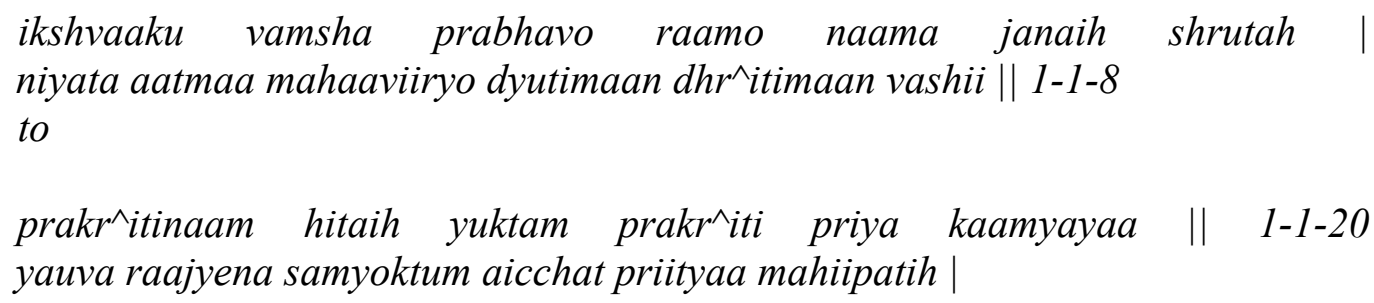

There is one born in the line of Ikshvaku and known by men by the name of Sri Ram. He is very powerful, radiant and resolute and has brought his senses under control. He is intelligent, sagacious, eloquent, glorious and an exterminator of foes.

"Rama being the possessor of suchlike merits, whose truthfulness alone is his courage, embodied with best intrinsic values, ever involved in the welfare of people, besides being the dear and eldest son of Dasharatha, and hence the king Dasharatha affectionately intended to establish such a Rama as crown prince to all intents and purposes of country's welfare...'[1-1-19b, 20, 21a]

An exhaustive cross-section from the epic, revealing valuable instructions on the art of administration that have a refreshing relevance today, is furnished below.

The administrative setup in Ayodhya is designed to provide the maximum happiness for the maximum number of people for the maximum period, based as it is on the principles of Dharma -righteousness and moral values. [Verses BK 1-5-5 to BK 1-517]

kosalo naama muditah sphiito janapado mahaan |

nivishta sarayuu tiire prabhuuta dhana dhaanyavaan || 1-5-5

to

$\mathrm{gr}^{\wedge}$ iha gaadhaam avicchidraam sama bhuumau niveshitaam |

shaali tandula sampuurnaam ikshu kaanda rasah udakaam $\| 1-5-17$

A great kingdom named Kosala, a joyous and a vast one well flourishing with monies and cereals, is snugly situated on the riverbanks of Sarayu. [BK 1-5-5]

That city shines forth with well-laid great royal highways that are always wetted with water, and with flowers strewn and scattered on them. [BK 1-5-8]

That city is surrounded with gateways and archways; the front yards of buildings are well laid; it is lodges all kinds of machinery, weaponry and craftsmen. [BK14-10]

That Ayodhya is an impassable one for trespassers, owing to her impassable and profound moats, and she is abounding with horses, camels, likewise with cows and donkeys. [BK 1-5-13] 
With the throngs of provincial kings who come hither to pay dues pervade that city, and she is verily lustrous with residents of various other countries, and with traders, too. In such a city King Dasharatha dwells. [1-5-14].

Here we should note that it is mandatory to collect the pending dues in time and also extend the business with others properly and carefully. This is one of the points to be noted from Ramayana by the modern corporatists.

The housing is very dense and there is no place or ground unutilized, and all are constructed on well-leveled lands, and rice-grain is plentiful while the drinking water tastes like sugar cane juice. [BK 1-5-17]

The stanza advises the modern corporate(s) to maintain the basic amenities available in their organization and utilize the resources available very properly.

King Dasaratha of Ayodhya, who was Dharmic (righteous) and solely concerned with the welfare of his subject was assisted by a cabinet of eight ministers of pure and unblemished characters. The cabinet was the Executive Council and the administration of the kingdom was carried out in consultation with it. The king was advised and supervised by a council of eight Sages (Dhristi, Jayantha, Vijaya, Suraashtra, Raashtravardhana, Akopa, Dharmapaala, are seven, and Sumantra is the eighth one), whose sole wealth was non-attachment (vairagya) and wisdom (Gyaan) [9]. Thus they functioned, without fear or favour, solely motivated by the welfare of the people, and provided the very foundation of the administrative system. The opinion of these sages possessing self-restraint, headed by sage Vasishtha, was the law. Thus, the cabinet ruled the people. The king supervised the cabinet. The Sages controlled the king in turn. In all matters, the moral code of the Lord of the universe (Dharma) reigned supreme. This is well explained from the following slokas of Bala Kanda [from BK 1-7-1 to BK 1-7-24]

\section{to \\ taih mamtribhih mamtra hiteh nivishtaih $v r^{\wedge}$ ito.anurak \{\}taih kushalaih samarthaih $\mid$ sa paarthivo diiptim avaapa yuk\{\}tah tejomayaih gobhih iva uditah arkah || 1-7-24}

tasya amaatyaa gunair aasan ikshhvakostu mahaatmanah | mamtraj naah cha in` gitaj naah cha nityam priya hite rataah || 1-7-1

All the ministers are well versed in scriptures, they shun bad deeds, skilful ones in their duties with their senses regulated. Those great souls are affluent, knowers of all sciences, firmly courageous, and they are distinguished and quietsouls, and those ministers are true to their word. They are magnificent, patient and famed ones and they smile afore they converse. [1-7-6b, 8a] 
They are efficient in administration and their friendships are well examined by the king, and those ministers impose punishment even on their own sons, if situation demands it. [1-7-10]

In collections to their treasury and to militarise their armies they are dutiful, even an unfriendly person will not be tortured, if he were not really blameworthy. [1-7-11]

They are valiant ones with engineered enthusiasm, administrators of political science, clean persons and protectors of subjects of their kingdom at all times. [1-7-12]

The ministers of King Dasharatha, observe decency in the interest of the king and also of the kingdom, with diligence and with a truthful-eye. [1-7-16]

They acquired good qualities from their mentors and they are renowned by their expertise, and even in foreign countries they are famous for their intellectual determinations in all affairs. [1-7-17]

Accompanied with such of those effectual and good-natured ministers the exalted king Dasharatha ruled the earth. [1-7-20]

King Dasharatha, while observing through spies, and to protect people righteously, and to give a good governance to them, he forsook unrighteousness and became a generous king avowed to truthfulness alone, he ruled the earth, which rulership is renowned in all the three worlds. [1-7-21,22]

In the company of those ministers, who are conducive to the strategies, interested in the king and subjects as well, skilful and efficient ones, he that King Dasharatha obtained brilliance, like the rising Sun along with resplendent sunrays. [1-7-24]

A corporation is a congregation of various stakeholders, like customers, employees, investors, vendor partners, government and society. Its growth requires the cooperation of all the stakeholders. Hence it imperative for a corporation to be fair and transparent to all its stakeholders in all its transactions by adhering to the best corporate governance practices.

Quality of corporate governance primarily depends on following factors, namely:integrity of the management; ability of the Board; adequacy of the processes; commitment level of individual Board members; quality of corporate reporting; participation of stakeholders in the management; etc. Since this is an important element affecting the longterm financial health of companies, good governance framework also calls for effective legal and institutional environment, business ethics and awareness of the environmental and societal interests.

Hence, in the years to come, corporate governance will become more relevant and a more acceptable practice worldwide. This is easily evident from the various activities undertaken by many companies in framing and enforcing codes of conduct and honest business practices; following more stringent norms for financial and non-financial 
disclosures, as mandated by law; accepting higher and appropriate accounting standards; enforcing tax reforms coupled with deregulation and competition; etc.

However, inapt application of corporate governance requirements can adversely affect the relationship amongst participants of the governance system. As owners of equity, institutional investors are increasingly demanding a decisive role in corporate governance. Individual shareholders, who usually do not exercise governance rights, are highly concerned about getting fair treatment from controlling shareholders and management. Creditors, especially banks, play a key role in governance systems, and serve as external monitors over corporate performance. Employees and other stakeholders also play an important role in contributing to the long term success and performance of the corporation. Thus, it is necessary to apply governance practices in a right manner for better growth of a company.

King Dasharatha decides to perform an elaborate Vedic ritual, called Aswamedha yajna, Horse Ritual, to beget children. He being a considerate king in taking conscience of the courtiers, he discusses this aspect with the Vedic scholars and ministers of his court, beforehand [Verses BK 1-8-8 to BK 1-8-22]

\section{mama laalasya maanasya sutaartham naasti vai sukham | tadartham hayamedhena yakshhyami iti matir mama || 1-8-8 \\ to \\ iti uktvaa $n r^{\wedge}$ ipa shaardulah sachivaan samupasthitaan | visarjayitvaa svam veshma pravivesha mahaamatih || 1-8-22}

"My mind is tumultuous without quietude for I have no sons... for that reason, I wish perform Aswametha, Vedic Horse Ritual... this is my thinking... [BK 1-88].

Then the Brahman scholars along with Sage Vashishta and all other important personalities in their turn have blessed and honoured him, saying that "splendid is this idea..." thus, for that which is voiced by the king. [1-8-10]

Then King Dasharatha is gladdened on hearing the sayings of those Brahmans. And with happiness lurching on his eyes the king spoke to the ministers, "As advised by my Vedic teachers let the paraphernalia be procured... [1-8-13b, 14]

"Let peace invocations be prevailing and prospering, as ordained in the scriptures and tradition... [1-8-16, 17a]

"Scholarly Brahma-demons will be hunting for the faults alone in the course of this ritual... should the procedure of this ritual be depraved of its set rules, the performer gets ruined... [1-8-17b, 18a]

"Therefore, you all shall see as to how this ritual of mine be conducted and concluded procedurally, and all of you are evidently experts in conducting such rituals... isn't it! [1-8-18b, 19a] 
On listening the words of the king all the ministers adored and assured him saying, 'It will be conducted faultlessly as has been conducted earlier...' [1-8$19 \mathrm{~b}, 20 \mathrm{a}]$

Sumantra, the charioteer and one of the misters of King Dasharatha, having heard all about the king's desire to perform a Vedic ritual, said this in confidence to king details the importance of Sage Rishyasringa and beseeches the king to invite that sage to preside over the contemplated Vedic ritual, for that Sage's entry into any kingdom is auspicious for that land and people.

Here we should note that though all kinds of planning and arrangements have been done for a project after consultation with eminent in their fields in a Corporate, it should be lead by a person, who is faultless in his nature of duties.

At Book I, Chapter 21 (sarga) explains the need of giving training and experiences to the successor(s) of a Kingdom or a Corporate. Sage Vishvamitra asks King Dasharatha to send Rama to protect the Vedic ritual that is being conducted by him, from the demons that are constantly disrupting it. But Dasharatha is upset at this request. On enquiring details about those dangerous demons that are ravaging sage's ritual, King Dasharatha refuses to send young Rama along with Sage Vishvamitra on many an account, and thus confronts the Sage's wrath. To pacify sage Vishvamitra, sage Vashishta intervenes and convinces king Dasharatha to send Rama with sage Vishvamitra. While doing so, sage Vashishta enumerates the capabilities of sage Vishvamitra, his knowledge of weaponry. Vashishta also suggests that all those weapons will be given to Rama, if Rama is dispatched with Vishvamitra. At last, Dasharatha agrees to send Rama.

Sage Vishvamitra satisfied with the behaviour of Rama in obliging the orders of elders and performing the act that is assigned to him, gives many weapons to Rama, called shastra, astra-s.

\subsubsection{King Dasharatha's Advice to Sri Rama}

On the eve of Sri Rama's coronation, king Dasharatha summoned his darling son and tendered wholesome and mature advice on Administration based on his experience. [Verses from Ayo.Kan. 2-3-41 to Ayo.Kan.2-3-45]

kaamatastvam prakr^ityaiva viniito gunavaanasi || 2-3-41

gunavatyapi tu snehaatputra vakshyaami te hitam |

to

koshhthaagaaraayudhaagaaraih $k r^{\wedge}$ itvaa sanni chayaan bahuun || 2-3-44

tushhtaanuraktaprakr^itiryah paalayati mediniim |

tasya nandanti mitraani labdhvaa.amr^itamivaa.amaraah || 2-3-45

tasmaattvamapi chaatmaanam niyamyaivam samaachara |

King Dasharatha said: "My son, although you are a storehouse of merits, I wish to offer some friendly advice to you out of sheer affection. Resorting to even greater humility (than before), constantly keep your senses under control. Avoid vices born of lust and anger." 
[Note: Vices (vyasanani) according to Manu Smriti arising from lust include hunting, playing at dice, sleeping by day, slandering others, fondness for women, vanity and vices resulting from anger are tale-bearing, violence, vindictiveness, jealousy, fault-finding, squandering one's wealth, abusive speech, and cruelty in punishment.]

"Like the celestials becoming happy after obtaining the nectar, friends of a king (ruler of earth) are delighted when he fills the granaries and armories to the brim, making the common people delightful and happy. Hence, you too act like this."

\subsubsection{Rules according to both the direct and indirect methods of governance}

Ascertaining the conditions and loyalty of one's own people and the relative strength and intentions etc., of the neighbouring states through a network of spies. To make a tour of one's dominions and ascertain things personally, to invite direct petitions from one's subjects, hear their grievances and decide their cases on their own merits.

"Please your ministers and others (namely, the Army Commanders and Civic Guards) as well as people responsible for maintenance (against future contingencies) of numerous stores (of useful materials such as jewelry, gold and silver, textiles and ornaments) along with barns and armouries."

"The friends and allies of a King, who protects the earth with fostering care and whose subjects are not only loved by him as his children but are devoted to him in their turn, exult in the same way as the immortals did on securing nectar. Therefore, disciplining your mind, my son, conduct yourself well as instructed by me."

The importance attached to personal discipline and far-sightedness in matters of efficient administration will be evident from the foregoing.

\subsubsection{Guru Vasistha's advice to Bharata}

Guru Vasistha, after recalling the several incidents since the attempt to crown Rama as King, emphasised Bharatha that "not to ignore one's responsibility given".

"The king, your father, gave you the kingdom, and you are duty bound to honour your father's word".

The king, to honour his word, not only gave up Rama but sacrificed his own body.

\subsubsection{Sri Rama's advice to Bharata}

After their momentous and affectionate meeting at Chitrakut, Sri Rama addressed Bharata on the art of administration, which is exhaustively detailed in the Ayodhya Kanda of the epic known as the famous 'Kacchit Sarga'. [Ayo.K 2-100-1 to Ayo.K.2-100- 76]

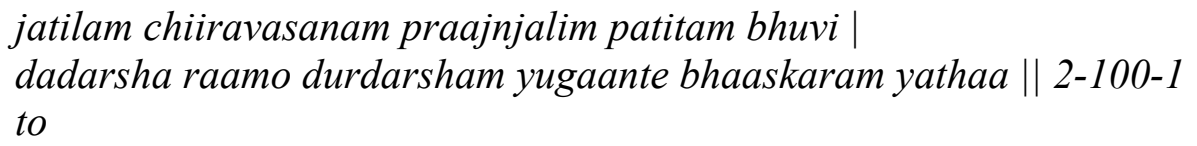


As Bharata was to rule the kingdom as per the King's promise to queen Kaikeyi, Sri Ram enquires of Bharata whether he was ruling the Kingdom efficiently. He was also asked to explain by Sri Rama why he had left his post of duty and come to the forest.

Rama gives instruction to Bharata as regards the duties of a king and the polity under an ideal monarchy under the pretext of enquiring about the welfare of his father and others.

Starting with human relations at home and Bharata's personal conduct and selfdiscipline, the questions cover his reverence and service to his parents, teachers and elders to ensure domestic harmony. It embraces all Departments of Government activity like Home Affairs, Defence, Foreign Affairs, Finance, Labour Relations, Agriculture etc.

"Are you rendering service to our father, oh my dear Bharata? Is the celebrated preceptor of Ikshvakus (Sage Vasishtha) being duly honoured by you?"

"Do you hold in high esteem gods and manes, dependents, elders, kinsmen of your father's age, the aged, the physicians as well as the Brahmanas?

"Do you respect Sudhanva, your teacher of the science of Archery who is equipped with knowledge relating to the use of excellent arrows both direct and remote-controlled and well versed in political economy?"

"I hope the ministers you have appointed are valiant like you- full of learning, who have controlled their senses, who are born of high pedigrees (cultured family) and know the meaning of signs (discreet and shrewd)."

"The sound advice given by experienced ministers well versed in the laws of truth and virtues is the very foundation on which the prosperity of a King rests."

"The learned in times of difficulty bring endless glory by solving knotty problems."

"I hope you prefer learned men to thousands of fools. No help will come to a king if he seeks advice from thousands of evil advisers or even ten thousands of them."

"Even if there is a single minister if only he is wise, brave, clever and discreet, he will bring fame and prosperity to a King big or small."

"He who does not get rid of a physician adept in devices of aggravating a disease, a servant intent on bringing disgrace to his master and a gallant warrior seeking kingly power, is himself destroyed by these persons."

"I hope the person appointed as your Commander-in-chief is ever pleased, full of resolution, is gallant and talented, is of spotless character and well-born and devoted and clever."

"Are the foremost of your skilled warriors being recognised by bestowing suitable honours by you?" (gallantry awards). 
"I hope you distribute (daily) provisions and distribute the monthly salary due to them at the proper time in a suitable manner and do not delay their payment (to prevent discontentment). For, salaried servants surely and positively get enraged even at their master when the distribution of their provisions and the disbursal of their salaries are delayed and that itself is a very great harm done to the State." (Labour Relations).

"Has a man of your own State, who is learned, clever, ready witted and capable of delivering messages correctly, who is able to distinguish between right and wrong, been appointed by you as an Ambassador, O Bharata?" (Foreign Affairs and Diplomatic assignment).

"Do you keep an eye on the eighteen functionaries of the enemies and fifteen functionaries of your side through three unknown, independent spies?"

We can note that the eighteen functionaries are : 1.The chief minister 2.The King's family priest 3 .The crown prince 4 .The generalissimo 5 .The chief warder 6.The chamberlain 7.The superintendent of jails 8.The chancellor of the exchequer 9.The herald 10.The government advocate 11.The judge 12.The assessor 13.The officer disbursing salaries to army men 14.The officer drawing money from the state exchequer to disburse the workmen's wages 15.The city Kotwal (mayor of the city) 16. The protector of the borders of a kingdom, who also performed the duties of a forester 17. The magistrate 18.The officer entrusted with the conservation of waters, hills, forests and tracts difficult of access. The fifteen functionaries of one's own side are the last fifteen of this very list, omitting the first three, viz., the chief minister, the family priest and the crown prince.]

Next Sri Rama instructs Bharata on the defence and protection of Ayodhya and enquires about the various aspects and measures designed for its prosperity (like water storage, well cultivated fields not depending on the vagaries of the monsoon (or rainy season), cattle wealth, peopled by highly delightful men and women, free from violence and fear etc.).

"Are the Vaisyas (who live by trade, agriculture and breeding and rearing cattle) loved by you? Are they thriving well in agriculture and animal husbandry?"

"Are the women folks well protected?"

"Are the forests which are the homes of elephants preserved by you?" (Wild life preservation and ecology).

"Are the milk-cows in abundance with you?" (dairying).

"Are all your fortifications fully supplied with wealth and provisions, arms and water, mechanical contrivances and equipped with artisans and bowmen?" (Defence installations in a state of readiness or full alert).

Regarding Financial management. 
"Is your income sufficiently large to meet your expenses and your expenditure comparatively less? (Balanced budget without deficit financing). I hope your wealth does not go to undeserving men."

"I hope the laws are administered justly and impartially. I hope the innocent do not suffer and the guilty are not let off without punishment due to greed (corruption)."

"I hope disputes between the rich and the poor are dealt with and judged impartially by the ministers. For, the tears from the eyes of those falsely convicted, destroy the sons and cattle of the king who rules the people for the sake of pleasures and not caring for equity and justice."

"Do you see to win over the elders, children and foremost physicians by gifts, a loving mind and polite words?" (Human Relations).

"Do you greet your teachers, and elders, ascetics, deities and unexpected visitors as well as the trees standing on cross roads (ecology) and the wise and learned Brahmins who have achieved the object of their life through character and austerities?"

"Do you avoid the fourteen failings of kings?"

We can note that these are the fourteen failings (vices) of a king: Atheism, Untruth, Anger, Carelessness, Procrastination, Neglect of the learned, Laziness, Slavery to the senses, Obsession with wealth, Counsel with those who do not know the proper way (perverted insight), Non-commencement of the decided issues, Absence of caution in keeping secrets, Non-use of the auspicious, Showing respect to all and sundry without any discrimination (e.g. getting up from the seat to receive anybody and everybody)].

" I hope you deal properly, after fully taking into account and knowing the ten evils born of lust, the five kinds of fortifications, the four expedients (recommended for kings), the seven important limbs of a state, the eight evils born of anger or the eight measures (conducive to the welfare of a state), the three worldly objects of human pursuits (Dharma, Artha, Kama) namely religious merit, material wealth and sensuous enjoyment or the three kinds of powers (namely energy or 'Utsaah-Shakti', the power of dominion or 'PrabhuShakti', and the power of counsel or 'Mantra-Shakti'.

"Do you hold consultation in accordance with scriptural injunctions with only four or three (selected) counselors collectively or severally to guard against a split among them and to prevent the secrets from leaking out?"

"Has your study of the Vedas borne fruit and are your undertakings successful?" "Has your learning borne fruit?"

Sri Rama concludes the illuminating address thus: 
"Having obtained as his share and ruled in the right way over the entire globe, a wise king holds sway over the earth and administering justice to the people quite in consonance with righteousness, surely ascends to heaven when detached from his body."

Rama asks Bharata why he has come to the forest, wearing robes of bark and antelope skin, abandoning Ayodhya kingdom. Bharata informs Rama about Dasaratha's death and requests Rama to take over the kingdom, endowed to him as per succession. Rama says that since king Dasaratha allotted two different duties to the two of them one enjoining the exile of his elder brother being binding on him and the other bequeathing the kingdom to Bharata, they must be implicitly obeyed by both of them.

It is interesting to note that earlier Sri Ram had clearly told Lakshamana when he suspected Bharata's intentions, that Bharata was coming in agony and solely with the purpose of offering the Kingdom to Sri Rama. Hence, questions addressed to Bharata were obviously not intended for him but, over his shoulders, they were guidelines meant for the benefit of those who wished to get educated on the principles and art of efficient administration.

\subsubsection{Surpankha's advice to Ravana}

In Aranya Kanda (The Forest Trek) at Chapter [Sarga] 32, Demoness Shurpanakha advising King Ravana it is told that Demoness Shuurpanakha, who is disfigured by the high souled Lakshmana, and who is still perplexed with the fear of Lakshmana and her own craving for Rama as well, on displaying her misfortune to everybody that fearless rover Shuurpanakha spoke this very caustic sentence to Ravana, in the presence of his ministers. [Ara.Kan 3-33-1 to Ara.Kan 3-33-24]

\section{pramattah kaama bhogeshu svaira vr^itto nira.nkushah | samutpannam bhayam ghoram boddhavyam na avabudhyase || 3-33-2 \\ to}

para avama.ntaa vishayeshu sa.ngavaan

na desha kaala pravibhaaga tattva vit |

ayukta buddhih guna dosha nishcaye

vipanna raajyo na ciraat vipatsyate || 3-33-23

'A greedy king, who is addicted to sensual pleasures and who acts at his sweet will and pleasure is avoided by his subjects like the cremation fire."

"A king who fails to attend to his duties personally at proper moment, hastens his downfall and ruins himself and his realm."

"If a king is ruthless, stingy, indifferent, proud and arrogant, his subjects will not come to his rescue in his times of crisis."

"A king who thinks too much of himself, who is evasive, self-conceited and ever irritable has to be mortally afraid even of his own kith and kin." 
"Kings are said to be far-sighted because they can easily visualize the distant calamities with the aid of spies."

"That king alone who is discreet, erudite, self-controlled, grateful and who obeys the divine law, can rule his kingdom well."

"That king is verily worshipped by his subjects, who though physically asleep is mentally awake, and does not indiscriminately punish or reward them."

'A slanderer, one steeped in worldly pleasure, one who is not in tune with time and one who cannot discriminate the good from the bad, loses his empire and perishes soon."

In this way when Shuurpanakha extolled only his negative traits, he that lord of night-walkers Ravana, who holds only his pride, power and prosperity dear to him, pored them over in his mind and contemplated over a time. [3-33-24]

\subsubsection{In Aranya Kanda (The Forest Trek), Maareecha advises Ravana}

Maareecha advises Ravana to stay away from Rama with his own unpleasant experience with Rama's arrow when he was in Tataka forest, and portrays a gruesome picture of Rama to Ravana, asking him to not to meddle with Rama's affairs.

sulabhaah purushaa raajan satatam priya vaadinah $\mid$

apriyasya ca pathyasya vak\{\}taa shrotaa ca durlabhah || 3-37-2

to

\section{avashyam vinashishyanti sarve raavana raakshasaah | yeshaam tvam karkasho raajaa dur.hbuddhih ajita indriyah || 3-41-15}

"It will always be easy to get people who talk pleasantly, oh, king, but it is impossible to get them who talk judgementally and give suggestions that may be apparently insipid, but that are recuperative, more so, it is impossible to get listeners of such advises. [3-37-2]

"Any king of your like who is with a self-will, ill-will, ensorcelled by evil, and malicious in intent, that king alone ruins his own city-state, his own people, even himself, as a matter of actual fact. [3-37-7]

Maricha asks Ravana to look ahead of his future and not spoil his present state by taking the wrong path. It would be self-destructive and also spell ruin for the demons. But Ravana was adamant as a person who rejects medicine and prefers to die.

In every utterance, Maareecha repeats that not only Ravana but the entire demonic race is also going to ruin due to Ravana's impertinence. Finally when Ravana is heedless of these advises, Maareecha prepares himself to die by the arrow of an enemy, namely Rama, rather than by his own clansman, Ravana.

"Your ministers are not curbing you anywise when you scramble on a high road to self-ruination, hence they are indeed to be sentenced to death, but they are not being executed for their dereliction. [3-41-6] 
"Veracious ministers have to restrain a self-willed king when he relies on a wrong-route, isn't it. But you are unrestrained by your ministers though you are self-willed and though you are taking a wrong-route. [3-41-7]

"Probity, prosperity and pleasures, and even the popularity of the ministers are achieved at the beneficence of their master. [3-41-8]

"Contrariwise, oh, Ravana, all that beneficence of the king to ministers becomes futile when the king behaves perversely, and even the others, namely the subjects of kingdom, will derive distress by the negative virtue of their master. [3-41-9]

"The king alone is the root cause for probity and prosperity, isn't it. Therefore, oh, best prosperous one, in all situations the kings are to be safeguarded from the ill effects of influences. [3-41-10]

"It is impossible to govern kingdom, for a king with acridity, with hostility, or with immorality. [3-41-11]

The ministers with drastic notions not only pull down the king and kingdom, they themselves get ruined along with the king and kingdom. "In the world many saintly beings that are high-minded and pursuers of ethicality are completely ruined together with their kinsmen owing to the misdeeds of others. [3-41-13]

"Oh, Ravana, the subjects do not flourish while a lord with contrariety and coerciveness safeguards them, just like goats guarded by a fox. [3-41-14]

"All those demons will definitely ruin, oh, Ravana, to whom you are the acrimonious and malicious king with unconquered senses, though you have conquered the heaven. [3-41-15]

"What is the use of laming for myself as I foregathered this ghastly situation as in crow-palm-tree syndrome, but in this issue you alone are regrettable, for you are gong to completely ruin along with your military. [3-41-16]

\subsubsection{In Kishkindha Kanda (The Empire of Holy Monkeys), Vanara King Vali Advices to Sugreeva and his son Angada}

Vali recovers from his swoon and gives his parting messages to Sugreeva and Angada. He also gives his miraculous pendant, given by his father Indra, to Sugreeva and asks him to assume authority of Kishkindha kingdom, for he won it in this fight. Angada is advised to conduct appropriately for he is becoming a father-less son now. Then Vali breathes his last to pave the way for Seetha's search. [Verses Kish.Kan. 4-22-3 to Kish.Kan. 4-22-23]

sugriiva doshena na maam gantum arhasi kilbishaat |

$k r^{\wedge}$ ishyamaanam bhavishyena buddhi mohena maam balaat || 4-22-3

to

na ca atipranayah kaaryah kartavyo apranayah ca te |

ubhayam hi mahaadosham tasmaat a.ntara $d r^{\wedge} i k$ bhava || 4-22-23 
"Sugreeva, reckon me not by my iniquities, but reckon as one who is all the while forcibly hauled into this futurity owing to my impropriety and obduracy. [4-22-3]

"You realize that I am going to the abode of Time-god now itself, and hence propose yourself as king of this forest-dweller's kingdom, now itself. [4-22-5]

Vali's supremacy does not die with him. Here also he is taking a high profile and he himself is proposing the kingship to Sugreeva, without any grudge or grouse, on two counts. One, Sugreeva is the triumphant one and thus he shall get the kingdom forthwith, not Angada, as proposed by Hanuma. Next, Sugreeva is the next best choice for the kingship, rather than Angada, and a younger brother and also as a one-time prince regent. In either way the dying Vali is keeping his nobility high up, as an unrivalled champion and even as an elderly brother.

"Such as I am, I am indeed forgoing my life, kingdom, and this immense prosperity and even the unenviable glory which adduces that 'Vali is unkillable,' right away. [4-22-6]

"You have to accomplish Raghava's mission undoubtedly, and if it is unaccomplished there will be infraction on your part because you befriended him before an altar of fire, and you may even be punished for dishonouring him and your given word to him. [4-22-15]

Quietened by Vali's words and conducting himself befittingly and attentively in the given situation, Sugreeva has then taken that golden chain only when Vali authorised him. [4-22-18]

On giving away that golden pendant, and on seeing his son who is available nearby, readying himself towards his end that is setting in, Vali affectionately spoke to Angada. [4-22-19]

"From now on, observing time and place you have to tolerate pain or pleasure, endure mirth or misery on your going under the control of Sugreeva. [4-22-20]

"Oh dextrous Angada, as to how I have entertained you in whichever way you conducted yourself with me, Sugreeva may not approve of such a puerile behaviour of yours, if you resort to it. [4-22-21]

"Do not reach at his unfriendly ones, nor come near his enemies, oh, enemydestroyer Angada, you shall be in the control of Sugreeva attending to the purposes of your lord with self-control. [4-22-22]

"Do not conduct yourself with excessive friendliness or unfriendliness, as this pair of opposites itself has a flaw, therefore you cultivate an intermediary outlook." Vali thus spoke to Angada. [4-22-23]

\subsubsection{In Kishkindha Kanda, Hanuman Advices King Sugreeva}

Sugreeva on his enthronement and gaining an interval of rainy reason, lapses into lavish enjoyment of sensual pleasures. His indulgence becomes overindulgence and makes him to forget his promise-oriented duty to search for Seetha. As an intelligent minister, 
Hanuman approaches Sugreeva and enlightens Sugreeva about his duty for the requital of help rendered by Rama. Ordering Niila, a commander of monkey forces, for foregathering all monkey troops within fifteen days, Sugreeva re-enters his palace-chambers, dragged by his sensual pleasures [from Kish.Kan.4.29.9 to Kish.Kan.4.29.15 \& Kish.Kan.4.32.10 to Kish.Kan.4.32.

raajyam praaptam yashah caiva kaulii shriih abhivarthitaa || 4-29-9

mitraanaam samgrahah sheshah tat bhavaan kartum arhati |

to

tat idam mitrakaaryam nah kaala atiitam ari.ndama |

kriyataam raaghavasya etat vaidehyaah parimaarganam || 4-29-15

"Acquired is the kingdom and glory as well, thus enriched is your dynastic prosperity, but foregathering friends is still remaining, and it will be apt of you to negotiate it. [4-29-9b, 10a]

"Indeed, he who really conducts himself punctually and amicably with friends, his kingdom, glory and valour will flourish. [4-29-10b, 11a]

"Matchless kingdom is his who can keep his treasury, army, friends and his own sovereignty - all these four, in equiponderance. [4-29-11b, c]

"Therefore, as the one with straightforward actions firstly you resort to an unimperilled course of action, lest any peril is imminent, and it will be apt of you to dutifully achieve the purpose of your friend Rama, for which alone Rama along with Lakshmana came to you, thus let your power preponderate. [4-29-12]

"Adversity thwarts him who comports himself with overenthusiasm only in selfindulgences, and who does not expeditiously strive for the sake of his friend leaving off all other activities of self-indulgence. [4-29-13]

Here Hanuma is indirectly reprimanding King Sugreeva for his lascivious way of living forgetting Rama's work. This can be said this way also in a general tone: "No misfortune can constrain him who strives enthusiastically and expeditiously for his friend's mission." But Hanuma's dutifulness is to be kept in view.

"One who belatedly functions for the present mission of his friend, he will indeed be unassociated with that mission, despite of the fact that he has once performed great deeds in respect of the same friend. [4-29-14]

"Hence, the task of our friend is delayed, oh, enemy-destroyer, searching for Vaidehi is Raghava's mission and let it be done. [4-29-15]

Here it is said that Sugreeva re-entered his palace-chambers. This is due to the impulsive nature towards his sensual gratifications. Though, in reality, monkey forces are being gathered, but that information is not passed on to Rama. This communication gap 
creates a furious emotion in Rama and he bids Lakshmana to go to Kishkindha and take Sugreeva to task, and even Lakshmana jumps on Sugreeva like a firebrand.

Sugreeva is disturbed at the unfounded anger of Lakshmana and wanted his ministers to elicit the cause for that anger. Hanuman informs Sugreeva that causing delay is the only fault of Sugreeva, for which Sugreeva is advised to pray for the mercy of Lakshmana personally.

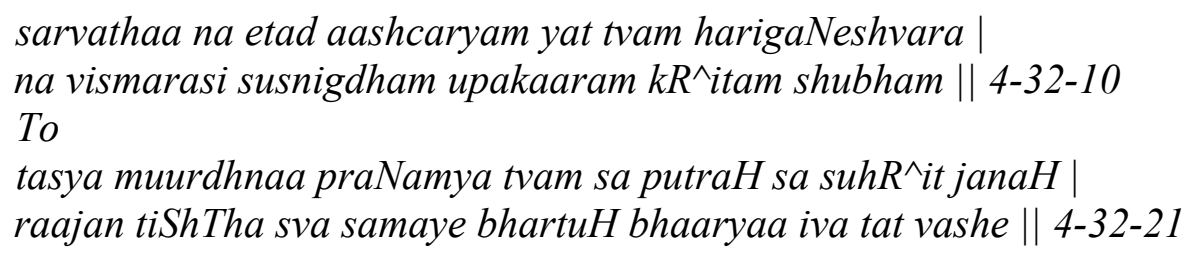

"Prostrate yourself before him along with your son, friends and relatives to pay deference, oh, king, and abide by your own accord you made with him remaining under his auspices, like a wife abiding in the care of her husband. [4$32-21]$

\subsubsection{Sri Ram's advice to King Sugrieva}

When Sugrieva fell at the feet of Sri Ram, he lifted Sugrieva up and embraced him, Sri Ram Said, "Sugrieva! A friend should be helpful at the right time. Only then the friendship will remain."

$$
\begin{aligned}
& \text { yat indro varShate varSham na tat citram bhaviShyati | } \\
& \text { aadityo asau sahasraaMshuH kuryaat vitimiram nabhaH || 3-39-2 } \\
& \text { candramaa rajaniim kuryaat prabhayaa saumya nirmalaam | } \\
& \text { tvat vidho vaa api mitraaNaam priitim kuryaat paraMtapa || 3-39-3 }
\end{aligned}
$$

\subsubsection{Vibhishana's Raj Neeti to King Ravana in Yudd Kandha}

Ravana's ministers, called to advise him on how to deal with Rama and His monkey army, flatter their king by recalling all his victories and wonder what he has to fear from Rama, or from anyone else.

$$
\begin{aligned}
& \text { pramatteShv abhiyukteShu daivena prahateShu ca } \mid \\
& \text { vikramaas taata sidhyanti pariikShya vidhinaa } k R^{\wedge} \text { itaaH || 6-9-9 }
\end{aligned}
$$

Vibhishana says there are three ways to face a powerful opponent: seek peace with him or appease him with gifts or try to sow seeds of dissension among his forces. Rama is invincible. Also on His side is Hanuman, who has proved his greatness by crossing the ocean.

$$
\begin{aligned}
& \text { balaani aparimeyaani viiryaaNi ca nishaa caraaH } \\
& \text { pareShaam sahasaa avaGYaa na kartavyaa katha.ncana } \| \text { 6-9-12 }
\end{aligned}
$$


Vibhishana tells the other demons, who gave Ravana the wrong advice, not to underestimate the enemy's strength, and that they should not dismiss Rama's valour as of no significance.

"A counselor is he, who after knowing the strength of the enemies and that of his own (master) and even so duly grasping with his intellect, the status quo, fall, or rise in military power like-wise on both sides, renders advice which is appropriate to the interest of his king."

He is certain that nothing but destruction awaits Lanka, unless Sita is handed over to Rama. Ravana should shed his needless animosity towards Rama, so that future generations of demons might leave in peace. Ravana, however, does not take his advice.

\subsubsection{Kumbhakarna's advice to King Ravana [Yudh.Kan.6-63-2 to Yudh.Kan.6-63-} 21]

Kumbhakarna abuses Ravana for his utter disregard of the earlier advices given by his well-wishers like Vibhishana, due to his sheer arrogance and neglect of the scriptures which enumerate the king's duties. Ravana replies to Kumbhakarna that bygone is a bygone and asks him to proceed to the battle-front. Then, Kumbhakarna reassures Ravana and promises him that all the adversaries would be destroyed by him in the ensuing battle. Hearing the lamentation of Ravana, Kumbhakarna laughed at a full volume and spoke as follows:

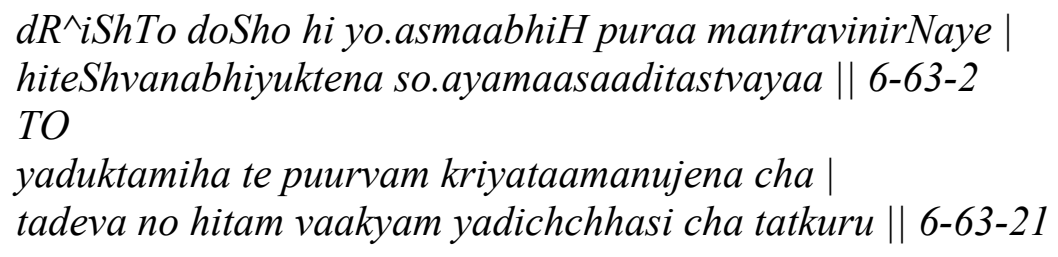

"The same bad consequence, which was imagined by us earlier while taking the final decision after our consultation, is faced by you now, due to your utter disregard of the words spoken by your well-wishers."

"O emperor! This course of action was not excepted by you at first. You did not conceive this consequence, only because of your sheer arrogance of power." "He who, abiding in power, performs duties to be done earlier at a later stage and duties to be done later, at an early stage, does not know what is a right course and what is a wrong course."

"Action done perversely, regardless of space and time, get spoiled like offering oblations without properly making the fire well-prepared."

"He, who acts according to an agreement done with his counsellors, considering three types of duties, by harassing five types of means, moves along a right course."

The three types of duties are conclusion of peace through conciliation, acceptance of allegiance through gift, and invasion, as a method of coercion. The harassing types 
comprise the method of initiating an actions, personality and material to be worked upon, time and place of action, provision against mischance, and chances of success.

"A king who wishes to execute am agreement as per law, understands it through his own intellect as well as the counsellors and discovers it through his friends, is on a right course."

"O king of demons! A man resorts to virtue or worldly gain or pleasure or all the three together or a twin combination of virtue and worldly gain or virtue and pleasure or worldly gain and pleasure or worldly gain and pleasure, according to an appointed time*."

"That sovereign king or crown prince, who, having heard which one is the best out of these three but does not keep it in mind, his extensive learning would be in vain."

"Whosoever deliberates with his counsellors and resorts to an act of with his counsellors and resorts to an act of bestowing gifts or conciliation or sowing dissension at appropriate occasion or exhibits valour or resorts to them all together or takes recourse to both right action and the reverse of it at the right time or pursues virtue or worldly gain or pleasure at the appropriate time, that intelligent person never confronts a misfortune in this world."

"A sovereign has to do an act here, looking into his welfare as a consequence along with his counsellors who make their subsistence by their intelligence and who understand the true state of the things."

"Men with brutal ideas, who are initiated in discussions, aspire to tell haughty things, without fully knowing the precepts of the scriptures."

"The words spoken by those who did not know the scriptures, who do not recollect the books dealing with practical life and who covet for abundant wealth are not to be implemented."

"Those men who talk with audacity, some inimical things in a friendly way, are to be kept out of deliberations, as they certainly spoil the work to be done."

"Some counsellors, colluding with some learned adversaries, spoil their king and make them do wrong deeds."

"The king should make-out those ministers who have been transformed by the enemy to their side (through bribery and other things) and are enemies though looking like friends, through their conduct when a final decision is being taken after deliberation."

"Outsiders find out the fickleness of a ruler, who is led away by false appearances and quickly performs the acts"

"A king who disregards an enemy and does not protect himself, indeed faces disappointing occurrences and would be removed from his position." 
"That advice which was tendered to you earlier by vibhishana is beneficial to us. Do whatever you wish to do."

\subsubsection{Ravana's Deathbed Advice To Sri Ram \{Yudh Kanda\}}

To Lakshman's surprise, Ravan opened his eyes and raised his arms to salute Ram, "If only I had more time as your teacher than as your enemy. Standing at my feet as a student should, unlike your rude younger brother, you are a worthy recipient of my knowledge. I have very little time so I cannot share much but let me tell you one important lesson I have learnt in my life. Things that are bad for you seduce you easily; you run towards them impatiently. But things that are actually good for you fail to attract you; you shun them creatively, finding powerful excuses to justify your procrastination. That is why I was impatient to abduct Sita but avoided meeting you. This is the wisdom of my life, Ram. My last words. I give it to you".

After these words, Ravan died. Sri Rama was fully aware of the Dharmic injunctions under which he had to operate under all circumstances.

"Whichever Dharma you follow with steadfastness and according to the principles, may that Dharma protect you."

"There is no greater Dharma for a Kshatriya than the protection of his subjects."

"There are only two pious paths, as has been said by the sages, wherein is the Dharma established, namely, Ahimsa (non-injury) and Satya (Truth)."

Rama's clear perception of the principles of universal brotherhood is very much evident in many instances throughout the pages of Ramayana [10]. It is based on protection, service during both adversity and prosperity, wealth for the happiness of others and a deep affection for others and no sense of victory over others. His devotion to his duty as a son is too well known. [11]

Ramayana is never tired of explaining again and again many moral qualities, the practice of which make a person pious and noble. Valmiki stresses the importance of many supreme duties in Ramayana that would have an ennobling influence on the person who practices them. Hence, one should cultivate these qualities in one's life. These may be listed briefly as follows:

Forgiveness (Kshamaa), Renunciation (Tyaaga), Gratitude (Krtajnataa), Equanimity (Samadarsitva), Purity of the mind (Shuddhamanah), Chastity (Pavitrataa), Courage (Shouryam), Protection of the individual (Rakshana), Non-violence (Ahimsa), Truthfulness (Satyam), Charity (Daanam), Worship of the guest (Atithipoojanam), and Love (Prema).

Ramayana elucidates that the most important aspect of Dharma is truthfulness (Satyam) and on this alone every other aspect of Dharma is established. No wonder Sri Rama's greatness is associated with his commitment to Truth.

As a contrast to these virtues (that one should acquire), Ramayana also presents a set of vices that would lead a person to degradation and destruction. Valmiki has brought 
out in clear relief the evil effects of these vices such as drunkenness, pride, lust, meateating, gambling, anger, greed, deceit, cruelty, mental impurity, indolence, gratifying the five senses, hate, jealousy, harsh tongue, treachery and so on.

A special mention is to be made regarding grief (Shoka) which has a special place in the epic of Ramayana. Sri Rama is seen in excessive grief and Valmiki considers grief as the greatest and a formidable enemy of man. He says grief destroys patience, knowledge, and everything and there is no enemy like grief. Sri Rama behaved like an ordinary mortal when he was stricken with grief, but as an energetic and enthusiastic person he never lost himself to grief.

Angada says; "Do not grieve in mind, for grief is the worst amongst vices. It kills a man just as an angry serpent kills its own brood." The philosophers of ethics identify four specific stages of the development of a character within a person. They are:

1. Strength of will

2. Extending the mental horizon and developing a better insight

3. Cultivating a sense of discipline and regular performance of one's own duties, and

4. Developing the attitude of honesty in thought, nobility in feeling and sincerity in action.

Sri Rama exhibited all these at every stage of his action. Therefore, he is rightly called 'Dharma Personified".

\section{Conclusion}

The most sacred Ramayana abounds with innumerable life-redeeming lessons. But in receiving a message, the receiver eagerly looks for something therein which will throw light upon and guide him in the most pressing problems of the day.

The advent of Rama Rajya (rajya=kingdom) verily implies the ushering in of prosperity and plenty, blessedness, bliss and peace on earth and goodwill among men. If such a state of true happiness and brotherhood is to come about then all fear and uncertainty must vanish from man's heart. However, fear will persist as long as there exist suspicion, distrust and disbelief amongst men. To eliminate distrust and suspicion all falsehood, deception, crookedness and untruth must go. Only then mutual trust and love will spring up between man. Truth alone can do this. The power of truth is that power which has made the memorable name of Harishchandra forever immortal and renowned, the power that will vanquish and exterminate falsehood and untruth from this fair earth of ours.

There is no doubt, if these principles are immediately adopted, sincerely cherished and earnestly practised, real Rama Rajya will come about on earth not merely for one kingdom, nation or country, but for the whole world. It will be Rama Rajya for the entire humanity.

\section{References}

[1] Goldman R. The Ramayana of Valmiki: An Epic of Ancient India. Princeton, New Jersey: Princeton University Press; 1984.

[2] Valmiki. Srimad Valmiki Ramayan. Gita Press Gorakhpur; 2020.

[3] Pollock S. The Ramayana of Valmiki: An Epic of India: Volume II: Ayodhyakanda. Princeton, New Jersey: Princeton University Press.; 1986. 
[4] Macdonell AA. The Epics: A History of Sanskrit Literature. New York: D. Appleton and company; 1900.

[5] Doniger W. Shadows of the Ramayana: In The Epic Voice Greenwood Press. 2002.

[6] Sharma A, editor. Hiltebeitel's India's Epics: Writing, Orality, and Divinity. The Study of Hinduism, Columbia: University of South Carolina Press; 2003, p. 114-38.

[7] Shafer R. A Guide to Historical Method. Illinois: The Dorsey Press; n.d.

[8] Bhatt G. Analysis of the Ramayana 2006.

https://www.boloji.com/articles/6001/analysis-of-the-ramayana (accessed February 10, 2019).

[9] Narayan RK. The Ramayana. New Delhi: Vision Books; 1987.

[10] Adams C a., Larrinaga-González C. Engaging with organisations in pursuit of improved sustainability accounting and performance. Accounting, Audit Account J 2007;20:333-55. doi:10.1108/09513570710748535.

[11] Fallon O. Introduction to Bhatti's Poem: The Death of Rávana (Bhatțikāvya). New York: New York University Press; 2009. 
This page is left intentionally blank 